\title{
Ventricular Escape Beat by ECG Finding
}

National Cancer Institute

\section{Source}

National Cancer Institute. Ventricular Escape Beat by ECG Finding. NCI Thesaurus. Code C90483.

An electrocardiographic finding of a compensatory ventricular complex that occurs following a prolonged RR interval. (CDISC) 